\title{
Using Inuit traditional ecological knowledge for detecting and monitoring avian cholera among Common Eiders in the eastern Canadian Arctic
}

\author{
$\underline{\text { Dominique A. Henri }}^{1,2}$, Frankie Jean-Gagnon ${ }^{3}$ and $\underline{H}_{\text {. Grant Gilchrist }}{ }^{1}$
}

\begin{abstract}
In recent decades, traditional ecological knowledge (TEK) has played an increasing role in wildlife management and biodiversity conservation in Canada and elsewhere. This study examined the potential contribution that Inuit TEK (which is one aspect of Inuit Qaujimajatuqangit or Inuit traditional knowledge) could offer to detect and monitor avian cholera and other disease-related mortality among Northern Common Eiders (Somateria mollissima borealis) breeding in the eastern Canadian Arctic. Avian cholera is an infectious disease (Pasteurella multocida) that has been a major conservation issue because of its potential to cause high rates of disease and mortality in several bird species in repeating epizootics; it has spread geographically in North America since the 1940s. In 2004, Inuit hunters from Ivujivik, Nunavik, Québec, were the first to detect avian disease outbreaks among Northern Common Eiders nesting in northeastern Hudson Bay and western Hudson Strait. Laboratory analysis of bird tissues confirmed avian cholera in that region. From 2007 to 2009, we collected Inuit TEK about mortality among Common Eiders and other bird species north and west of where the outbreaks were first detected. During interviews in the communities of Kimmirut, Cape Dorset, Coral Harbour, and Igloolik, Nunavut, Canada $(n=40)$, Inuit participants reported seeing a total of 8 Common Eiders and 41 specimens of other bird species either sick or dead in northern Hudson Strait, Hudson Bay, and Foxe Basin. Most of the observed disease and mortality events were at sea, on sea ice, or on small nesting islands. Such events probably would have gone undetected by biologists, who were mainly monitoring avian cholera outbreaks on large nesting islands in that region. Inuit participants readily recalled details about the timing, location, and numbers of sick and dead birds that they observed. Some reported signs of disease that were consistent with avian cholera. Inuit also revealed knowledge of two past bird mass mortality events that took place about 60 years and a century ago. Those interviewed indicated that that bird mass mortality events potentially caused by avian cholera had not occurred in the study area prior to 2004 , supporting the hypothesis that avian cholera emerged only recently in the eastern Canadian Arctic. This study demonstrated that TEK can be a valuable tool for monitoring future avian cholera outbreaks and other wildlife diseases in remote regions.
\end{abstract}

Key Words: avian cholera; Common Eider; community-based monitoring; Inuit Qaujimajatuqangit; Nunavik; Nunavut; traditional ecological knowledge

\section{INTRODUCTION}

Traditional ecological knowledge (TEK) is increasingly recognized by both wildlife management practitioners and academic researchers as a source of information that can contribute to biodiversity conservation worldwide (Mailhot 1993, Mauro and Hardison 2000, Gilchrist et al. 2005, Houde 2007, Berkes 2012). The proponents of TEK have argued that its consideration can benefit scientific research and resource management through the provision of unique information at local scales, and that TEK collection can potentially enhance the meaningful involvement of resource users in decisions that affect them (Berkes and Henley 1997, Berkes et al. 2007, Gagnon and Berteaux 2009). In northern Canada for example, there has been increasing use of TEK and Inuit Qaujimajatuqangit (IQ; Inuit traditional knowledge) in land-claim processes, wildlife comanagement, environmental impact assessment, communitybased monitoring, natural resource and protected areas management, and climate change research (Ferguson and Messier 1997, Duerden and Kuhn 1998, Ferguson et al. 1998, Riedlinger and Berkes 2001, ACIA 2005, Mallory et al. 2006). Although TEK and IQ studies have contributed diverse information on the ecology and demography of Arctic marine birds (Nakashima 1991, Robertson and Gilchrist 1998, Mallory et al. 2003, Gilchrist et al. 2005), avian disease is an area that has rarely been explored by this type of research. We addressed this gap by examining how Inuit traditional ecological knowledge contributed to the detection and ongoing monitoring of avian cholera outbreaks among Common Eiders nesting in the eastern Canadian Arctic. This investigation was conducted by researchers from Environment and Climate Change Canada and the University of Oxford in close partnership with four Hunters and Trappers Organizations based in Nunavut, Canada. We reviewed a single case study in which recent outbreaks of avian cholera led to significant mortality among Northern Common Eiders (Somateria mollissima borealis) breeding in the northeastern Hudson Bay and Hudson Strait region. The Common Eider duck has a longstanding cultural significance for the Inuit who have developed a broad ecological understanding of the species (Reed 1986, Nakashima 1991). Eiders are currently a source of meat, eggs, and feather down for the Inuit in both Nunavut and Nunavik (Henri 2007, 2012, Gilliland et al. 2009, Savard et al. 2011). The timing of eider summer harvest activities conducted by the Inuit (June and July) coincides with the time of year when Common Eiders appear most vulnerable to avian cholera outbreaks when nesting densely in colonies (Buttler 2009, Iverson 2015).

In this context, and because Inuit hunters were the first to detect signs of avian cholera outbreaks in the Canadian Arctic in 2004 and expressed concerns about this disease, we documented Inuit

${ }^{1}$ Wildlife Research Division, Science and Technology Branch, Environment and Climate Change Canada, ${ }^{2}$ School of Geography and the Environment, University of Oxford, ${ }^{3}$ Department of Biology, Carleton University 
TEK on disease and mortality events among Common Eiders and other bird species. Our general aim was to explore how Inuit can help understand the temporal and geographical occurrence of avian cholera among Common Eider populations, and to examine the potential for Inuit to participate in and improve monitoring of avian cholera in free-ranging birds in the Arctic. Specifically, we considered the strengths and limitations of this source of knowledge when assessing the spatial and temporal spread of disease among Common Eiders. Given that prior to 2004, scientific research had not documented avian cholera among Common Eider populations nesting in the Canadian Arctic, we also wanted to assess through Inuit TEK whether mass mortality events, i.e., when 20 or more birds are found dead in the same area within one nesting season, had occurred historically among Common Eiders breeding in this region or instead were a recent phenomenon. Finally, we wanted to identify the benefits of Inuit participation in monitoring disease emergence among wildlife populations occurring in remote polar regions.

\section{METHODS}

\section{Background}

Avian cholera is one of the most important naturally occurring bacterial (Pasteurella multocida) diseases affecting birds (Friend 1999, 2006). Mortality from avian cholera has been reported primarily from waterfowl in North America, but natural infection has occurred in over 180 wild bird species worldwide, representing at least 47 different families of birds (Samuel et al. 2007). This avian disease was first observed in the wild in Texas around the 1940s and has since spread northward across the United States and Canada (Gordus 1993, Friend et al. 2001). In the wild, avian cholera is suspected when large numbers of dead ducks or geese are found in a short time period. Most wild birds with avian cholera are found dead with no premonitory signs. They generally die quickly, within 12 to 48 hours of being infected with the bacterium Pasteurella multocida (Friend 1999). Disease transmission among wild birds can occur both directly via birdto-bird contact, as well as environmentally through ingestion or inhalation of aerosolized bacteria in contaminated water or sediments (Samuel et al. 2007). Avian strains of P. multocida rarely infect humans and are not considered a high risk to human health. Nevertheless, humans should avoid direct contact with infected birds in order to prevent potential contamination (Samuel et al. 2007). Avian cholera currently stands out as a major conservation issue because of the magnitude of losses it causes (particularly among waterfowl), the broad spectrum of species affected, the annual frequency of epizootics, and its continually increasing geographic spread in North America (Friend 1999, Friend et al. 2001, Samuel et al. 2007, Descamps et al. 2012). The Common Eider (Somateria mollissima) or mitiq (in Inuktitut) is a largebodied, long-lived, and highly gregarious migratory sea duck that is found in Arctic and subarctic coastal habitats in the circumpolar Arctic. It often breeds in colonies on islands and low-lying points of land (Goudie et al. 2000). In the eastern Canadian Arctic, the Northern Common Eider (S. m. borealis) subspecies breeds in colonies located in northern Hudson Bay, Hudson Strait, Ungava Bay, and Foxe Basin (Goudie et al. 2000, Gilliland et al. 2009). Breeders from Arctic Canada winter in two distinct areas. Some migrate in the fall through Hudson Strait and along the Labrador and Newfoundland coasts to winter in Atlantic Canada, while others cross the Davis Strait to winter in southwestern Greenland, returning in spring to breed in Canada (Mosbech et al. 2006). Common Eiders are considered particularly vulnerable to contagious diseases, including avian cholera, because they breed colonially and are gregarious even during the non-breeding season (Goudie et al. 2000, Christensen 2008).

\section{Avian cholera epidemic in the low eastern Arctic}

Local Inuit residents hunting in the area near Ivujivik, Nunavik, Québec, were the first to detect signs of avian cholera presence in the eastern Canadian Arctic (Henri et al. 2010, Gaston, unpublished manuscript; Kwan, unpublished manuscript; Simard, unpublished manuscript). In July 2004, Inuit hunters from Ivujivik observed hundreds of Common Eiders dying from disease in and around small nesting colonies in Digges Sound $\left(62^{\circ} 38^{\prime} \mathrm{N}, 78^{\circ}\right.$ $\left.18^{\prime} \mathrm{W}\right)$, on Mansel Island $\left(62^{\circ} 14^{\prime} \mathrm{N}, 79^{\circ} 27^{\prime} \mathrm{W}\right)$ and on Nottingham Island $\left(63^{\circ} 17^{\prime} \mathrm{N}, 77^{\circ} 54^{\prime} \mathrm{W}\right.$; Fig. 1; Iverson 2015). Laboratory analyses of eider carcasses collected by Inuit hunters and scientific researchers later confirmed the presence of avian cholera (Fig. 1; Iverson 2015). Although significant outbreaks of avian cholera had been confirmed among Common Eiders in southern populations, notably in the Gulf of St. Lawrence, Canada, and coastal Maine, United States (Goudie et al. 2000), biologists had never identified this disease among Common Eiders nesting in the Canadian Arctic before 2004 (Iverson 2015). Given the fact that avian cholera is apparently an emergent disease in this region, the term "avian cholera outbreak" refers here to the presence of single or multiple disease cases found in an area.

From 2004 to 2014, avian cholera outbreaks were confirmed among eiders through laboratory analyses of tissues conducted by the Canadian Wildlife Health Cooperative (Fig. 1). In addition, this disease was confirmed among six other bird species in the region, i.e. Herring Gull (Larus argentatus), Glaucous Gull (Larus hyperboreus), Great Black-backed Gull (Larus marinus), Black Guillemot (Cepphus grylle), Canada Goose (Branta canadensis), and Northern Pintail (Anas acuta). Avian cholera epizootics notably occurred annually on the breeding grounds of the largest Northern Common Eider colony in the Canadian Arctic, where a long-term scientific mark-recapture program has been conducted since 1996 (Buttler et al. 2011, Henri 2012, Iverson 2015). This colony is located on a small rocky island (Mitivik Island; $0.24 \mathrm{~km}^{2}$; $64^{\circ} 02^{\prime} \mathrm{N}, 81^{\circ} 47^{\prime} \mathrm{W}$ ) within the East Bay Migratory Bird Sanctuary, Southampton Island, Nunavut and comprises between 4000 and 8000 Common Eider breeding pairs depending on the year (Descamps et al. 2012, Iverson 2015). From 2005 to 2014, Common Eider carcasses and swab samples (oral and cloacal) collected from female eiders from the colony were submitted to the Canadian Wildlife Health Cooperative for analysis and avian cholera was diagnosed by either serology or molecular genetic analysis as the cause of death each year (Buttler et al. 2011, Legagneux et al. 2014, Iverson 2015). In the summer of 2006, for instance, avian cholera killed over 3500 Common Eiders (that is, more than $32 \%$ of nesting females) between late June and early August (Buttler 2009). Over the course of this avian cholera epidemic, the abundance of breeding pairs at the East Bay colony declined by nearly $50 \%$ with little evidence for compensatory reproduction in the years immediately following the epidemic peak (Iverson 2015). 
Fig. 1. Location of avian cholera (Pasteurella multocida) outbreaks among Common Eiders (Somateria mollissima) in northeastern Hudson Bay, Hudson Strait, and Ungava Bay from 2004 to 2014. The original source of avian disease or mortality sighting and the detection methods used to confirm the presence of avian cholera are presented for each site (adapted from Iverson 2015).

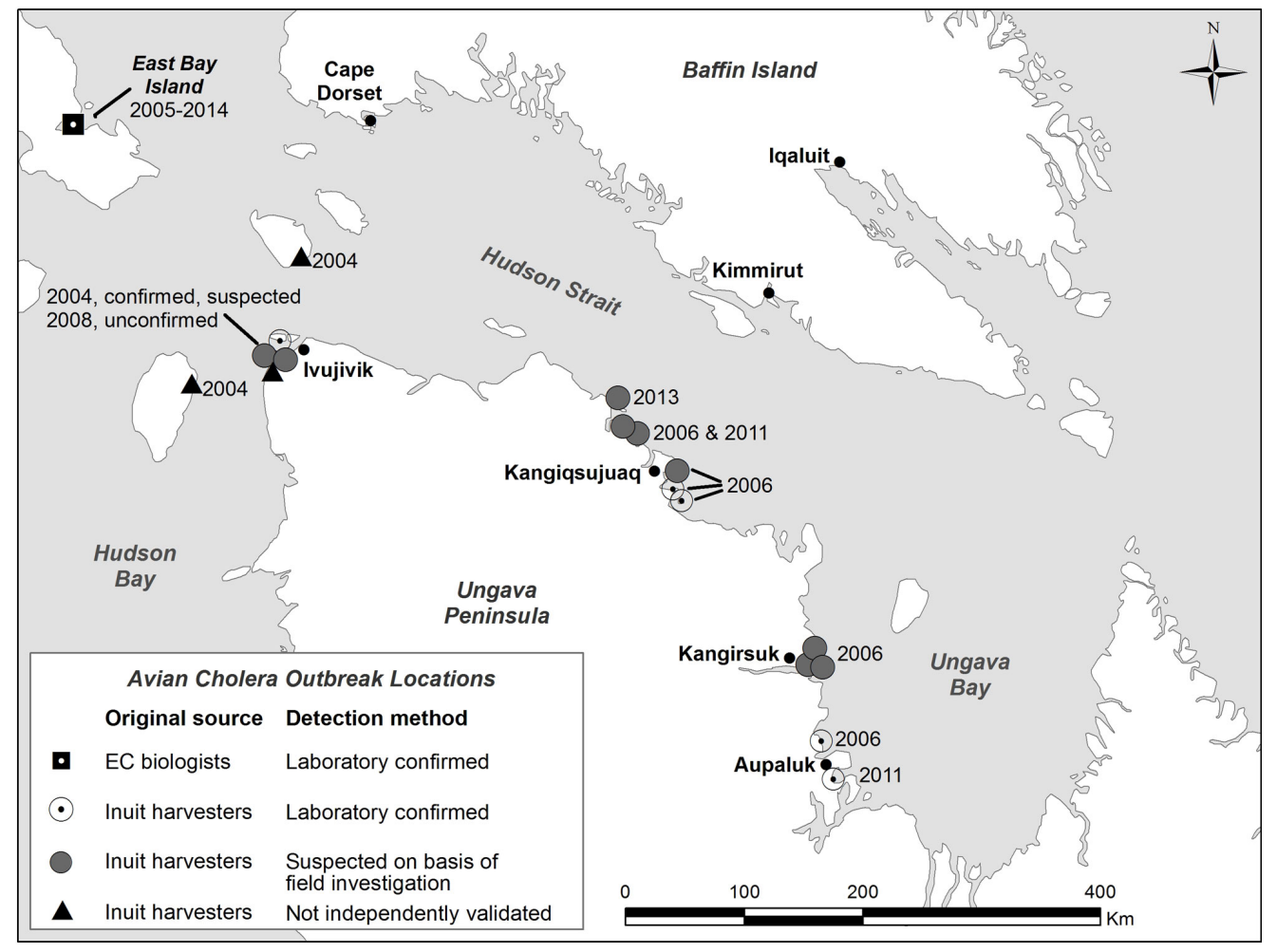

Consequently, avian cholera generated concern for the abundance and overall health of the Northern Common Eider population nesting in the eastern Canadian Arctic (Descamps et al. 2009, Iverson 2015). The geographical scope and potential spread of this disease however remained largely unknown because the dynamics of avian cholera outbreaks, i.e., determinants of disease frequency, severity, and spread, are still poorly understood in this remote region (Samuel et al. 2005, Descamps et al. 2012, Harms 2012).

\section{Defining Inuit traditional ecological knowledge and Inuit Qaujimajatuqangit}

Although the term "traditional ecological knowledge" came into widespread use only a few decades ago, it has been an integral part of hunter-gatherer cultures for millennia (Berkes 2012). Many definitions were proposed for TEK, depending on the context and objectives of its application (Johnson 1992, Mailhot 1993, Pierotti and Wildcat 2000, Whytes 2013). For example, Berkes defined traditional ecological knowledge as: "A cumulative body of knowledge, practice, and belief, evolving by adaptive processes and handed down through generations by cultural transmission, about the relationship of living beings (including humans) with one another and with their environment" (Berkes 2012:7). TEK is therefore both cumulative and dynamic, building on the experiences of people as they adapt to change. It is often an attribute of societies with historical continuity in resource use in a particular environment (Houde 2007). TEK refers to a knowledge-practice-belief system, implying a component of local knowledge of species and their interactions with other environmental phenomena; practice in that people gain ecological knowledge and experience as they carry out livelihood activities; and belief reflected in people's perception of their role within ecosystems, as ecological aspects of traditional knowledge cannot be divorced from social and spiritual values (Usher 2000, Berkes 2012).

Inuit TEK has further been recognized as one aspect of Inuit traditional knowledge or Inuit Qaujimajatuqangit (literally, "that which has long been known by the Inuit" [White 2006:241]), which encompasses all aspects of traditional Inuit culture, including values, language, social organization, knowledge, life skills, perceptions, and expectations (Wenzel 2004, Lévesque 2014; Wenzel, unpublished manuscript). Arnakak (2000) described IQ as a holistic and evolving body of knowledge and cultural insights held by Inuit about society and human nature and experience, including human-environment relationships: "In fact, IQ is a living technology. It is a means of rationalizing thought and action, a means of organizing tasks and resources, a means of organizing family and society into coherent wholes." Thus, IQ is broader than Inuit TEK and incorporates wider societal and cultural values, practices, experiences, norms, and worldviews. As G. Wenzel (unpublished manuscript) explained: "IQ in its principal sense is concerned not only with Inuit knowledge of the environment and how [Inuit interact] with its living and non-living 
elements, but also the values (ethos) that guide these interactions and the ontological system that animates and gives meaning to these values." Because this study focused on very specific aspects of IQ, namely Inuit knowledge about avian disease and mortality events, we employed the term TEK whenever appropriate throughout this manuscript, while recognizing that Inuit TEK should be viewed as part of Inuit Qaujimajatuqangit.

Some researchers, including ourselves, have differentiated the terms local ecological knowledge (LEK) and traditional ecological knowledge; the former referring to a subset of TEK presenting "current local knowledge acquired more recently over the lifetime of individuals" (Gilchrist et al. 2005:22). We intentionally examined traditional ecological knowledge (TEK) particularly because Inuit use of the eider has a very long history, and because we explicitly aimed to gather both short-term and long-term historical information on avian disease and mortality events. This study emphasized direct observations as well as oral tradition and historical information transmitted over two or three generations.

\section{Field methods}

This study was jointly undertaken by academic and government researchers in close collaboration with hunters and trapper organizations (HTOs) from each of the four participating communities. Local HTOs gave permission, advice, and support to carry out this work, which was conducted under a research license (0103408R-M) from the Nunavut Research Institute. Field research was carried out in the communities of Kimmirut $\left(64^{\circ}\right.$ $30^{\prime} \mathrm{N}, 80^{\circ} 17^{\prime} \mathrm{W}$; population: 389$)$, Cape Dorset $\left(64^{\circ} 13^{\prime} \mathrm{N}, 76^{\circ} 32^{\prime} \mathrm{W}\right.$; population: 1441), Coral Harbour $\left(64^{\circ} 08^{\prime} \mathrm{N}, \quad 89^{\circ} 09^{\prime} \mathrm{W}\right.$; population: 891$)$, and Igloolik $\left(69^{\circ} 22^{\prime} \mathrm{N}, 81^{\circ} 48^{\prime} \mathrm{W}\right.$; population: 1682), Nunavut (Fig. 2; Government of Canada 2016). These communities were chosen for several reasons: (1) their geographical proximity to avian cholera outbreaks confirmed from 2004 to 2014 in the eastern Canadian Arctic (Fig. 1), (2) the strong willingness of local people and organizations to participate in this project, and (3) the presence of residents who were knowledgeable about past disease and mortality events occurring among eiders. Forty individual interviews were conducted by $\mathrm{DH}$ with experienced Inuit hunters and elders in July 2007 and from February to May 2009. In each of the communities, participants were selected by HTOs in collaboration with interpreters and territorial government Conservation Officers, who were asked to identify local "eider experts"; that is, "persons recognized by their peers as knowledgeable" about eider ecology (Ferguson and Messier 1997:18). In order to document diverse local perspectives on avian disease, we specifically encouraged HTO representatives and conservation officers to identify women experts as well. Inuit women typically butcher and cook eiders and other birds more than men, which makes them well positioned to detect internal symptoms of avian disease. As a result, we ensured that we interviewed at least two women in each community. The interviewees ranged in age from their early 30 s to late 80 s, and most engaged in harvesting activities on a part-time or full-time basis or had just recently retired from harvesting (throughout this paper, the words "participant," "interviewee," "respondent," and "informant" are used synonymously and interchangeably to designate interviewed participants). In all cases, informants were asked to sign a consent form describing participant rights and conditions for release of recorded information. All 40 individual interviews with Inuit hunters and elders were conducted in participants' language of choice (Inuktitut or English). A professional interpreter was present during all interviews to translate on an as-needed basis. Most interviewees expressed themselves in Inuktitut while the interviewer initially asked questions in English. A local high school student was also hired in three communities (Kimmirut, Cape Dorset, and Coral Harbour) to assist the researchers. All interviews were audiorecorded with permission, and biogeographical information was collected on acetate overlays placed on topographical maps at scale 1:250,000.

Fig. 2. Map of the study area and location of the four surveyed communities.

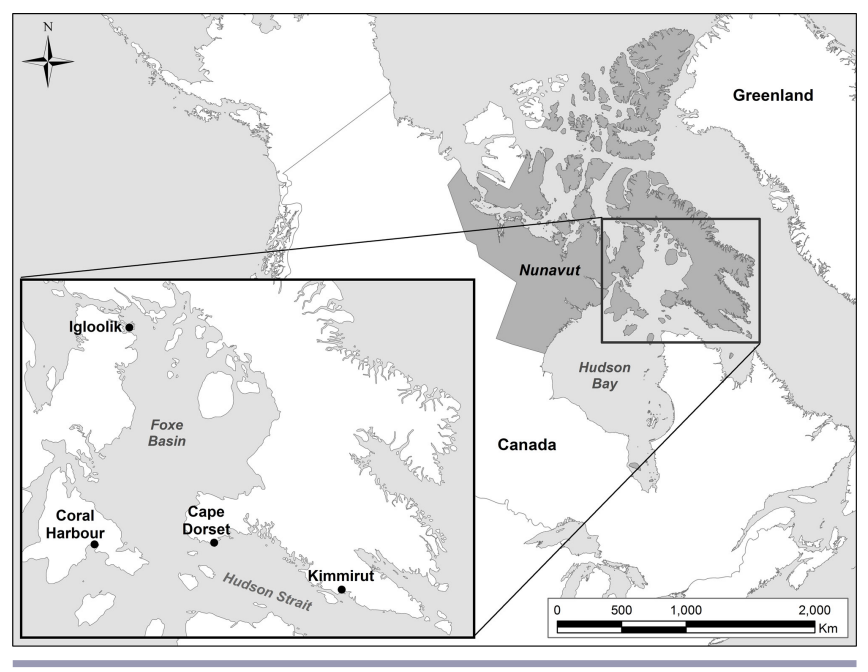

A semidirected interview format was preferred, allowing for open and flexible conversations and avoiding the rigidity of questionnaires (Huntington 1998, Rubin and Rubin 2005). Despite the flexible nature of the interviews conducted, 16 questions were asked to the participants (Table 1) who would add to or skip topics depending on their expertise. Two main themes were covered: (1) the respondents' geographic and temporal knowledge of disease and mortality events among Common Eiders and other bird species, and (2) their harvesting practices and uses of the Common Eider. Given that avian cholera is an infectious disease that affects the Common Eider but also other avian species, such as Canada Goose, Snow Goose (Anser caerulescens), Herring Gull, Thick-billed Murre (Uria lomvia), and King Eider (Somateria spectabilis), present in its distributional range (Samuel et al. 2007), we documented Inuit TEK on disease and mortality among Somateria mollissima and other bird species. With this approach we aimed to gather as much information as possible that could inform where avian cholera may have occurred. During the interviews, observations on avian mortality resulting from disease were specifically queried; known mortality events resulting from other causes, e.g., wounds from hunting, fishing bycatch, and boat trauma, were excluded from the results. We also sought specific information on observations of any symptoms observed by Inuit that may be associated with avian cholera, such as mucous discharges from the mouth and bill, matted and stained feathers, erratic behavior, bleeding on the surface of the heart muscle, gizzard, and liver, and lower portions 
Table 1. Questions asked and themes discussed during interviews with participants in Kimmirut, Cape Dorset, Coral Harbour, and Igloolik, Nunavut.

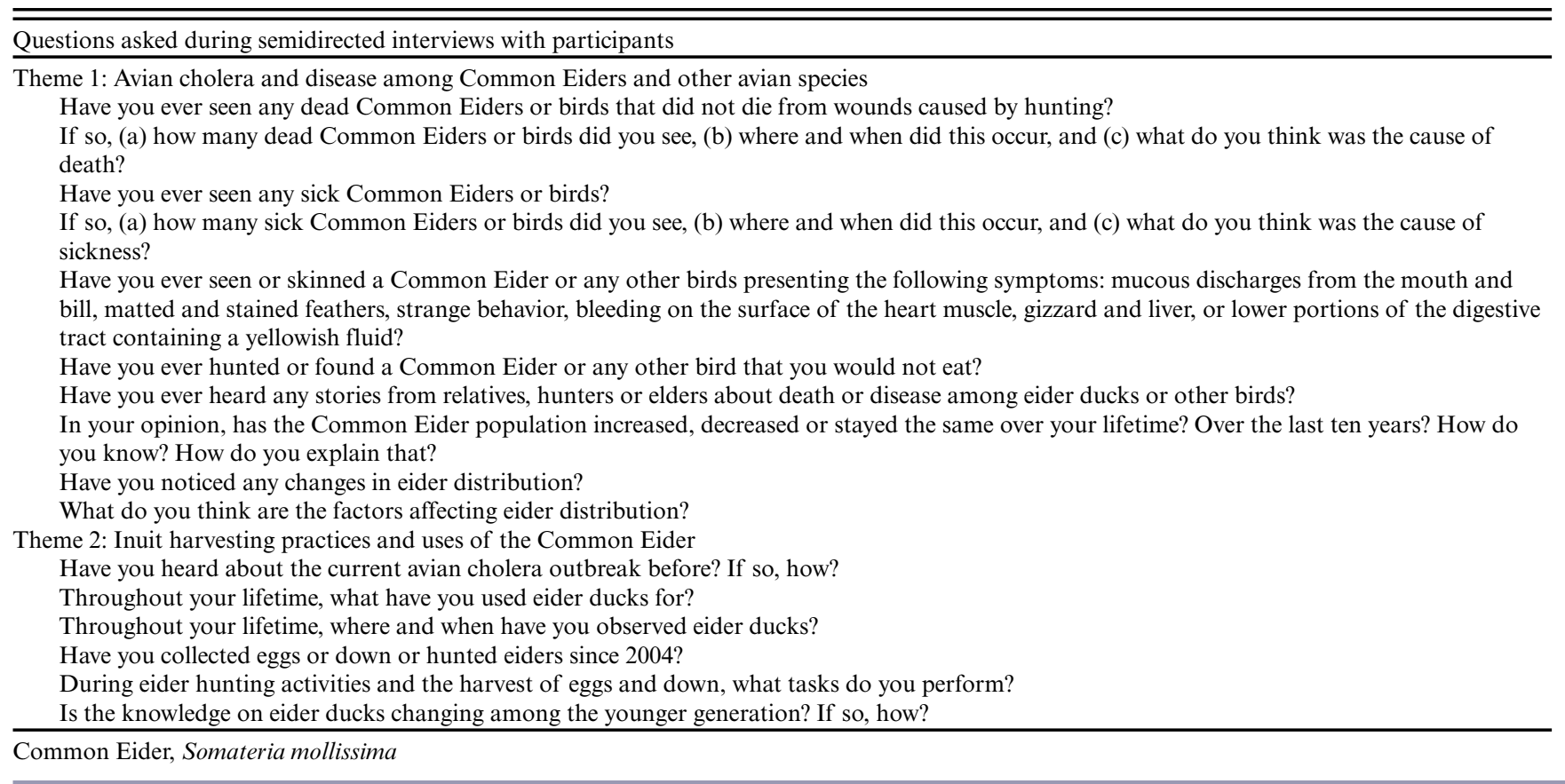

of the digestive tract containing a yellowish fluid (Friend 1999, Friend et al. 2001). All recorded interviews were subsequently transcribed and transcripts were coded manually (Kitchin and Tate 2000). Recurrent or key themes were analyzed through an interpretative approach seeking to make use of the data produced through the identification of basic descriptive units, categories, and patterns and the tracing of connections among these (Kitchin and Tate 2000). In addition, relevant information from the transcripts was exported into an Excel database to generate basic descriptive statistics.

Between February and March 2009, preliminary findings were reported back to the communities of Coral Harbour, Cape Dorset, and Kimmirut. Subsequent meetings held with HTO board members and local conservation officers provided us with additional opportunities to discuss and validate early findings, and to obtain further feedback on the research process.

\section{Limitations}

Limitations and biases of this study should be acknowledged. First, the information collected through interviews represented a partial sample of all knowledge held about avian disease and mortality in the four surveyed communities. Responses received during interviews might have been influenced by the level of familiarity of the researcher with the local culture, the lack of recall of specific factual information by interviewees (e.g., in some rare instances, participants could not recall precise year, month, or location of specific observations), the personality and gender of the interviewer, and the loss of information through the translation process (Brook and McLachlan 2005). In addition, given that TEK knowledge holders were also resource users, respondents might have been reluctant to reveal proprietary or sensitive knowledge. However, we felt interviewees were comfortable sharing their knowledge because of the presence of strong local support for this project, the absence of public controversy over the management of Common Eiders, and the shared concern between Inuit, scientists, and wildlife managers regarding avian cholera and its potential effects on bird populations in Nunavut. In spite of such possible limitations, the nonrandom sampling technique that we applied and the reasonable sample size in four communities strengthens our degree of confidence in the representativeness of the information we collected. We interviewed approximately $17 \%$ of eider hunters in Kimmirut, $11 \%$ in Cape Dorset, $100 \%$ in Coral Harbour, and $13 \%$ in Igloolik (percentages were calculated by using the total number of eider hunters reported per community in the Nunavut Wildlife Harvest Study [NWMB 2004]). Participants' strong willingness to engage in and contribute to this project also demonstrated the openness that characterized the research process in each community. Finally, we acknowledged that the cause of avian disease and mortality events observed in the wild by Inuit cannot be confirmed unless further laboratory analyses are performed on bird tissues. However, this study intended to assess the prevalence of birds observed sick or dead over long multigenerational time scales, and to examine the potential for Inuit to participate in and improve wildlife disease monitoring practices in the Arctic moving forward.

In the results section, factual observations made by interviewees were carefully separated from inferences, and direct observations made by participants were separated from those they reported from other hunters, elders, or relatives (Usher 2000). To preserve anonymity, informants were identified by codes comprising numbers and letters. Numbers designated the chronological rank of participants in the interview process, and letters indicated their 
Table 2. Participants' uses of the Common Eider (Somateria mollissima) presented by community and types of uses.

\begin{tabular}{lcccc}
\hline \hline Community & \multicolumn{4}{c}{ Participants' uses of the Common Eider (\%) } \\
\cline { 2 - 5 } & $\begin{array}{c}\text { Hunting } \\
\text { (meat) }\end{array}$ & $\begin{array}{c}\text { Egg- } \\
\text { picking }\end{array}$ & $\begin{array}{c}\text { Down } \\
\text { collection }\end{array}$ & Making of accessories \\
\hline Kimmirut $(\mathrm{n}=10)$ & 90 & 100 & 80 & 20 \\
Cape Dorset $(\mathrm{n}=10)$ & 90 & 100 & 90 & 20 \\
Coral Harbour $(\mathrm{n}=10)$ & 80 & 50 & 40 & 20 \\
Igloolik $(\mathrm{n}=10)$ & 90 & 90 & 30 & 30 \\
Total $(\mathrm{n}=40)$ & 87.5 & 85 & 60 & 32.5 \\
\hline
\end{tabular}

community of residence: A for Kimmirut, B for Cape Dorset, C for Coral Harbour, and D for Igloolik. Here, the terms dead eiders and other dead birds designate specimens that died from disease inferred (but not confirmed) by participants.

\section{RESULTS}

Inuit harvesting practices and uses of the Common Eider

All participants in this study actively engaged in one or many of the following activities: eider hunting for meat, eider egg picking for consumptive purposes, feather down picking for personal or commercial use, and the making of clothes and accessories from various parts of the eider (Table 2). The harvesting practices and uses of the Common Eider by Inuit had direct implications for the temporal and geographical scope of their ecological knowledge. Eider harvesters concentrated their observations of the species at specific locations and times of the year.

For instance, eider hunting was concentrated during spring and fall migration in all participating Inuit communities. By contrast, egg and down harvesters observed Common Eiders during the months of June and July when eider eggs and down were readily available on nesting islands, which were mostly accessed through extensive boat travel. It is important to note that the timing of eider observations by egg and down pickers coincided with a time of year when Common Eiders appeared especially vulnerable to avian cholera (Buttler 2009, Iverson 2015). Thus, between 2004 and 2008, 25 respondents $(60 \%)$ visited Common Eider colonies during the same season as recent avian cholera outbreaks were confirmed in the eastern Canadian Arctic, and 13 of these participants $(52 \%)$ observed dead eiders or other birds since 2004 onward. In addition, although all sites of eider egg and down picking used by the 40 interviewees throughout their lifetime were mapped during the interview process, participants could not recall the exact years of use in most cases. When asked about the frequency and timing of their visits to eider colonies, many respondents could not provide specific quantitative information on their harvesting activities. However, they tended to recall specifically the season, year, and circumstances associated with unusual events, such as sightings of sick or dead birds.

The geographical range of observations of sick or dead birds reported by participants was mostly within a $100 \mathrm{~km}$ radius of their community and showed strong individual variation. Participants reported hunting eiders mostly opportunistically as they travelled on the land or during trips aiming to hunt other species, e.g., ringed seals or snow geese. As such, they did not identify any specific areas used for eider hunting. All Common Eider egg and down picking areas visited by interviewees were plotted on a single map per community and the number of resource users was identified for each site (Figs. 3 to 6). These maps indicated that egg and down harvesting trips never extended beyond a 215 kilometer radius of each of the communities. This illustrated the limited geographical scope of knowledge held, which study participants readily acknowledged.

Fig. 3. Participants' use of the Common Eider (Somateria mollissima) and observations of sick or dead Common Eiders and other birds in Kimmirut, Nunavut.

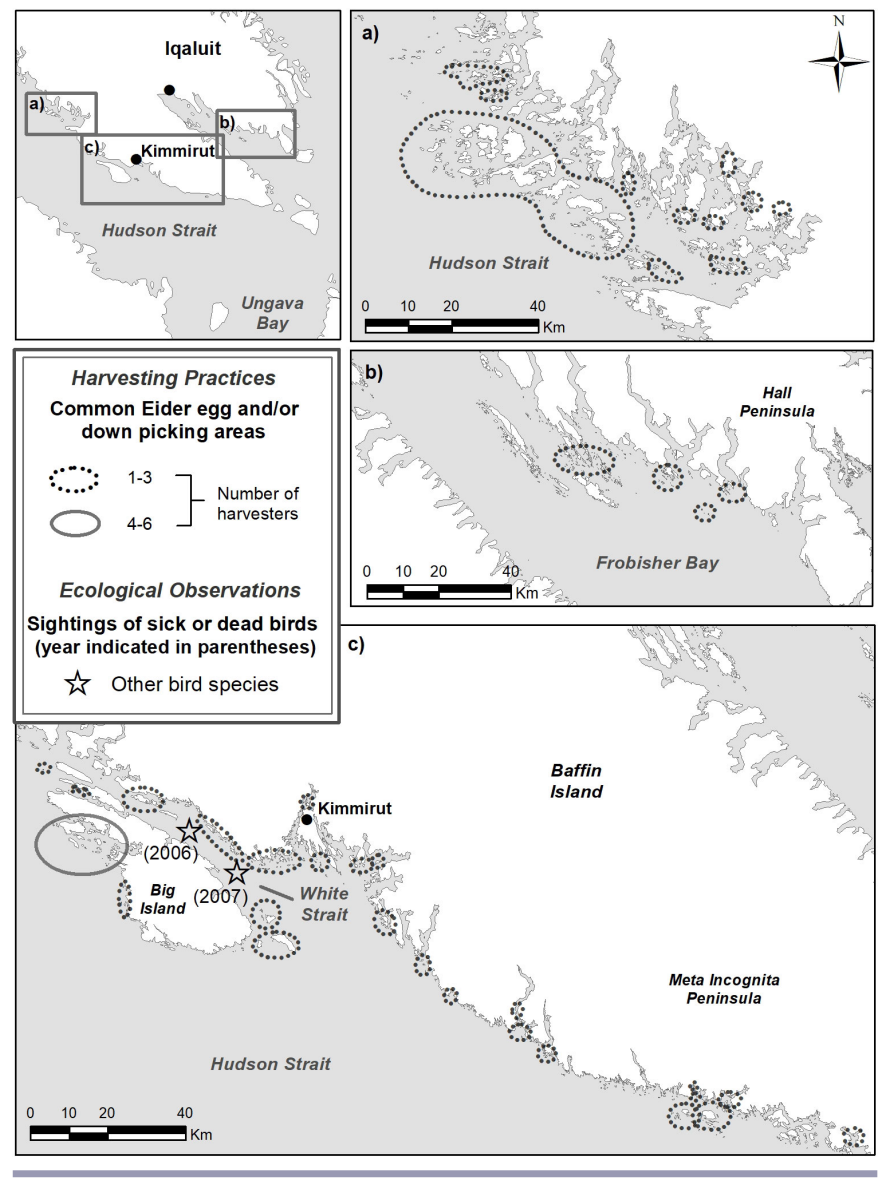

The spatial and temporal scope of interviewees' knowledge about Common Eiders reportedly was influenced by the availability of local eider nesting colonies, the presence of opportunities to travel to eider harvesting sites, and by individual preferences and 
motivation. One informant (6B) summarized: "How far and when we go on the land depends on the availability of boats, food, and gas supplies, ATVs [all-terrain vehicles], and people to travel on the land with. It also depends on what people like to do."

Fig. 4. Participants' use of the Common Eider (Somateria mollissima) and observations of sick or dead Common Eiders and other birds in Cape Dorset, Nunavut.

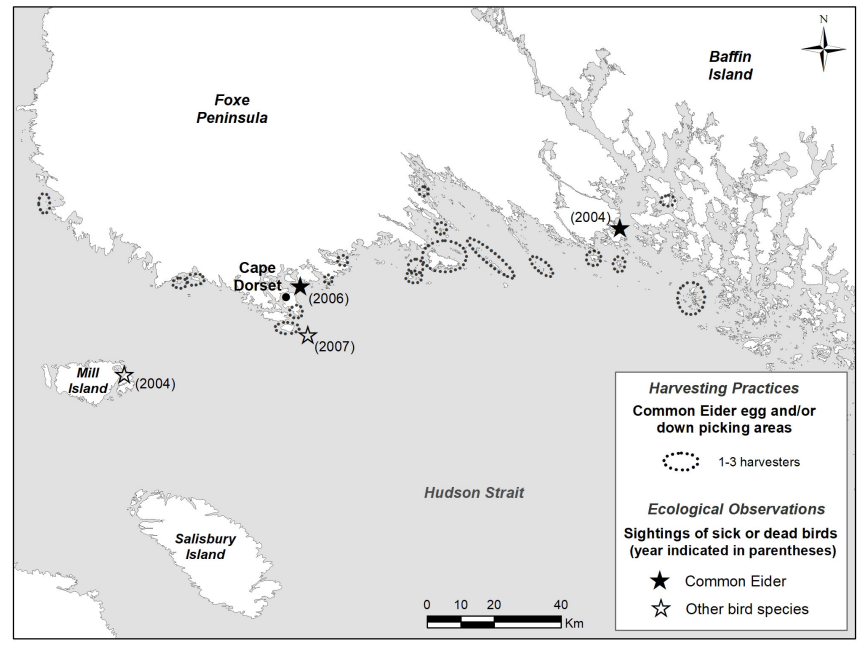

Avian disease and mortality events reported by participants Out of the 40 participants interviewed, 15 of them (38\%) had observed sick or dead birds, including Common Eiders and other avian species, or had personally heard a story from other hunters or relatives about it (Table 3, Figs. 3 to 6). In the community of Kimmirut, at the far eastern margin of Hudson Strait, none of the 10 respondents had directly observed any sick or dead Common Eiders during their lifetime, but three reported sightings of other marine birds that were sick or dead (Fig. 3). As they were travelling by boat in spring 2007, two participants (2A, 6A) observed three sick Thick-billed Murres and one sick Herring Gull floating in the White Strait $\left(62^{\circ} 48^{\prime} 23^{\prime \prime} \mathrm{N}, 70^{\circ} 29^{\prime} 05^{\prime \prime} \mathrm{W}\right.$; located about $30 \mathrm{~km}$ away from Kimmirut). According to the interviewees, these birds were alive but apparently sick because they were floating on their side, unable to hold their head straight. In spring 2006, also when he was travelling by boat, another participant (3A) reported seeing one dead Herring Gull floating in open water in the same area. In Kimmirut, none of the interviewees had ever personally observed a mass mortality event among eiders or other birds. When asked if they had heard any story about avian disease or mortality from others, two elders independently told a similar story: "Many eiders were killed on an island by the lightning. I did not see the eiders myself. I don't know exactly where it happened... That was a long time ago. I think it may have occurred in the early 1900s. I heard this story from my grandfather" (10A)

Of the 10 respondents from Cape Dorset (located about $360 \mathrm{~km}$ west of Kimmirut), none had witnessed any mass mortality event among Common Eiders or other bird species. Interviewees reported occasional encounters of dead birds (between 2004 and 2007 only; Fig. 4). In July 2004, a participant (3B) observed one dead Common Eider on an island. He explained that, even if showing no visible signs of illness, this bird had probably died from disease given the absence of wounds caused by hunting. In July 2006, another participant (5B) saw one dead Common Eider $\left(64^{\circ} 14^{\prime} 56^{\prime \prime} \mathrm{N}, 7^{\circ} 29^{\prime} 54^{\prime \prime} \mathrm{W}\right)$ floating in open water in the Hudson Strait as he was travelling by boat about $3 \mathrm{~km}$ northeast of Cape Dorset. The participant did not detect lesions consistent with wounding or disease and attributed the death to an unknown illness. The same respondent (5B) described a dead Thick-billed Murre (64'10'01"N, 76 $\left.20^{\prime} 04^{\prime \prime} \mathrm{W}\right)$ floating in the Hudson Strait in 2007; he also made this observation from his boat. Another respondent (6B) observed a dead Herring Gull on Mill Island $\left(63^{\circ}\right.$ $\left.58^{\prime} 56^{\prime \prime} \mathrm{N}, 77^{\circ} 43^{\prime} 59^{\prime \prime} \mathrm{W}\right)$ in the summer of 2004 . When asked about the stories they had heard on avian disease, two participants shared information that was similar to the stories reported in Kimmirut, in which an eider mortality event "caused by lightning" occurred "about a century ago" $(2 \mathrm{~B}, 8 \mathrm{~B})$.

Fig. 5. Participants' use of the Common Eider (Somateria mollissima) and observations of sick or dead Common Eiders and other birds in Coral Harbour, Nunavut.

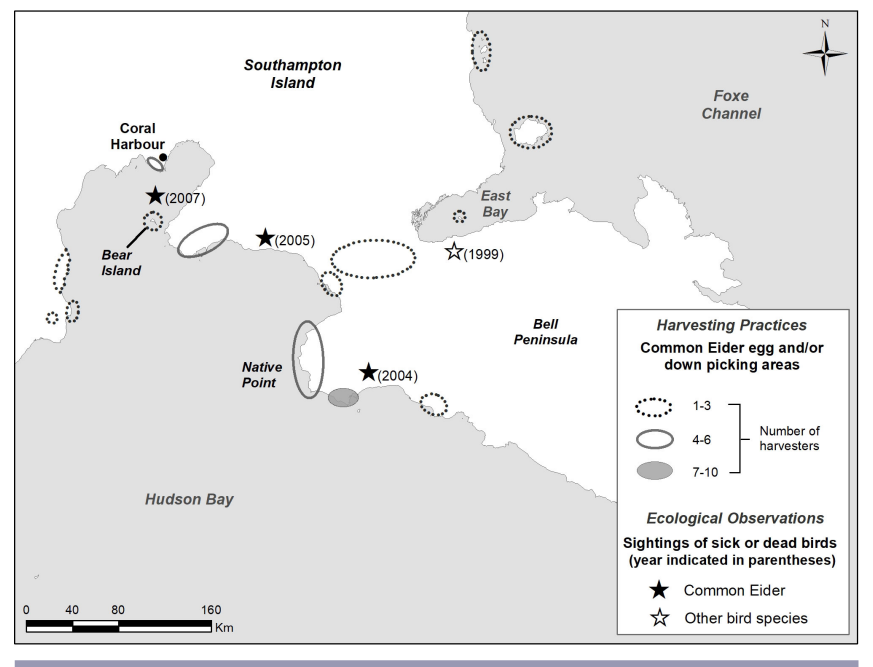

Fig. 6. Participants' use of the Common Eider (Somateria mollissima) and observations of sick or dead Common Eiders and other birds in Igloolik, Nunavut.

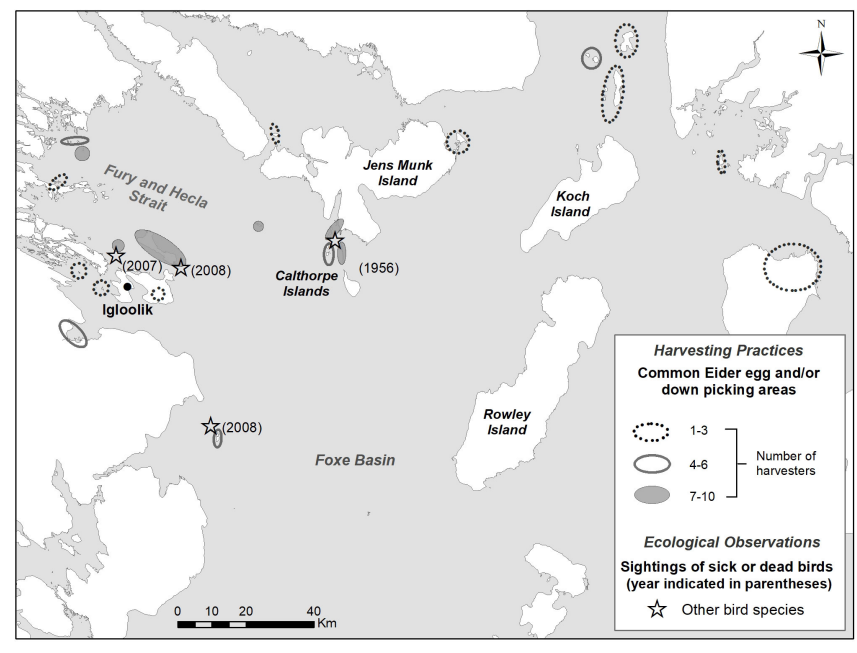


Table 3. Observations of disease and mortality events, population trends, and distributional changes among Common Eiders (Somateria mollissima) and other birds as reported by participants in Kimmirut, Cape Dorset, Coral Harbour, and Igloolik, Nunavut.

\begin{tabular}{|c|c|c|c|c|c|c|}
\hline \multicolumn{2}{|l|}{ Observations } & $\begin{array}{c}\text { Kimmirut } \\
(\mathrm{n}=10)\end{array}$ & $\begin{array}{l}\text { Cape Dorset } \\
(\mathrm{n}=10)\end{array}$ & $\begin{array}{l}\text { Coral Harbour } \\
(\mathrm{n}=10)\end{array}$ & $\begin{array}{l}\text { Igloolik } \\
(\mathrm{n}=10)\end{array}$ & $\begin{array}{c}\text { Total } \\
(\mathrm{n}=40)\end{array}$ \\
\hline \multicolumn{2}{|c|}{$\begin{array}{l}\text { Percentage of participants having observed sick or dead Common } \\
\text { Eiders }(\%)\end{array}$} & 0 & 20 & 40 & 0 & 15 \\
\hline \multicolumn{2}{|c|}{ Total number of sick or dead Common Eiders reported } & 0 & 2 & 6 & 0 & 8 \\
\hline \multicolumn{2}{|c|}{$\begin{array}{l}\text { Percentage of participants having observed other sick or dead } \\
\text { birds }(\%)\end{array}$} & 30 & 20 & 10 & 40 & 25 \\
\hline \multirow[t]{5}{*}{$\begin{array}{l}\text { Number of other sick or dead birds } \\
\text { reported }\end{array}$} & $\begin{array}{l}\text { Thick-billed } \\
\text { Murres }\end{array}$ & 3 & 1 & 0 & 0 & 4 \\
\hline & Herring Gulls & 2 & 1 & 0 & 0 & 3 \\
\hline & Canada Geese & 0 & 0 & 4 & 1 & 5 \\
\hline & Snow Geese & 0 & 0 & 0 & 6 & 6 \\
\hline & King Eiders & 0 & 0 & 0 & 23 & 23 \\
\hline \multirow{4}{*}{$\begin{array}{l}\text { Percentage of participants reporting } \\
\text { changes in Common Eider population } \\
\text { trend over the last } 10 \text { years }(\%)\end{array}$} & Declining & 20 & 20 & 0 & 0 & 10 \\
\hline & Stable & 20 & 10 & 0 & 30 & 15 \\
\hline & Increasing & 10 & 10 & 70 & 0 & 22.5 \\
\hline & Does not know & 50 & 60 & 30 & 70 & 52.5 \\
\hline \multicolumn{2}{|c|}{$\begin{array}{l}\text { Percentage of participants reporting changes in Common Eider } \\
\text { distribution }(\%)\end{array}$} & 60 & 70 & 70 & 90 & 72.5 \\
\hline
\end{tabular}

In Coral Harbour, four elders reported that they had recently observed dead or sick Common Eiders (Fig. 5). In May 2007, two participants $(2 \mathrm{C}, 7 \mathrm{C})$ saw one dead Common Eider lying on sea ice, as they were seal hunting at the ice floe edge near the community. During the same month, another Common Eider was found sick in the same area, unable to fly. In June 2004, one interviewee (4C) found one dead Common Eider on a nesting island; he observed yellow mucus around its bill, which he thought had been caused by a disease. The following year, in May 2005, another respondent (5C) saw three dead eiders close to their nests; the three specimens showed no apparent lesions or evidence of cause of death. Participants from Coral Harbour reported only one sighting of dead birds (other than Common Eiders). In June 1999, a respondent saw four dead Canada Geese inland, east of Native Point $\left(63^{\circ} 57^{\prime} 25^{\prime \prime} \mathrm{N}, 81^{\circ} 46^{\prime} 59^{\prime \prime} \mathrm{W}\right)$, showing a yellow substance on their abdomen (6C). None of the participants interviewed in Coral Harbour had observed or heard stories about avian mass mortality events that would have occurred prior to 2004. Although three respondents knew about the existence of a disease affecting Common Eiders nesting at East Bay (situated about $70 \mathrm{~km}$ east of the community), none of them had directly observed the recent mass mortality events reported by scientists conducting research at this colony. One interviewee (7C) travelled to East Bay in July 2002 to pick eggs and down but he did not notice any signs of eider duck mortality. In spite of its relative proximity to Coral Harbour, the colony of East Bay was seldom visited by local residents who generally performed their harvesting activities in smaller eider colonies that were easier to access near the community (Fig. 5).

Four participants out of $10(40 \%)$ reported finding dead waterfowl around the Igloolik area $(600 \mathrm{~km}$ north of Coral Harbour; Fig. 6). In spring 2008, two hunters (2D, 6D) who were travelling by boat found one dead Canada Goose and six dead Snow Geese floating in open water in two different locations $\left(69^{\circ}\right.$ $26^{\prime} 39^{\prime \prime} \mathrm{N}, 81^{\circ} 27^{\prime} 57^{\prime \prime} \mathrm{W}$ and $\left.68^{\circ} 59^{\prime} 14^{\prime \prime N}, 81^{\circ} 06^{\prime} 38^{\prime \prime} \mathrm{W}\right)$. The two interviewees explained that these birds had probably died from disease because they did not exhibit any wounds caused by hunting. In July 2007, another participant (3C) reported seeing three dead King Eiders on an island, lying close to their nests $\left(69^{\circ}\right.$ $\left.30^{\prime} 22^{\prime \prime} \mathrm{N}, 82^{\circ} 05^{\prime} 50^{\prime \prime} \mathrm{W}\right)$. The specimens had apparently "died from disease and not from hunting" and the participant did not notice any visible signs of illness. In the late 1950s (probably in 1956 based upon recollected family events that occurred that year), one informant (9D) observed about 20 dead King Eiders on Calthorpe Islands $\left(69^{\circ} 30^{\prime} 53^{\prime \prime} \mathrm{N}, 80^{\circ} 17^{\prime} 52^{\prime \prime} \mathrm{W}\right)$, as she was travelling by dogteam on a spring hunt (Fig. 6). The participant did not know the cause of death. Both King and Common Eiders were nesting on the islands at the time. Another respondent who had been camping with her family on Calthorpe Islands also recalled hearing about this avian mortality event in the 1950 s, but did not observe it directly (10D).

Among the 40 participants who were interviewed in Kimmirut, Cape Dorset, Coral Harbour, and Igloolik, 15 participants (38\%) had observed sick or dead Common Eiders and/or other birds during their lifetime. In total, interviewees saw eight Common Eiders (one sick; seven dead) and 41 specimens of other bird species (four sick; 37 dead) either sick or dead (Table 3) in northern Hudson Strait, Hudson Bay and in the Foxe Basin. Respondents were travelling by boat during eight out of the $14(57 \%)$ avian disease or mortality events they reported, and most of these events took place at sea, on sea ice, or on small nesting islands. Importantly, 12 out of $14(86 \%)$ avian disease or mortality events directly observed by participants occurred between 2004 and 2008 (Fig. 7); these incidents happened during a period when avian cholera outbreaks were confirmed (from 2004 to 2014) in the northeastern Hudson Bay, Hudson Strait, and Ungava Bay area (Figs. 1 and 7; Buttler et al. 2011, Legagneux et al. 2014, Iverson 2015). 
Fig. 7. Number of avian disease and mortality events reported by participants from all four surveyed communities (Kimmirut, Cape Dorset, Coral Harbour, and Igloolik) and bird mortality (in number of birds) at the East Bay eider colony (2004-2014). Individual mortalities at East Bay were confirmed through laboratory analysis.

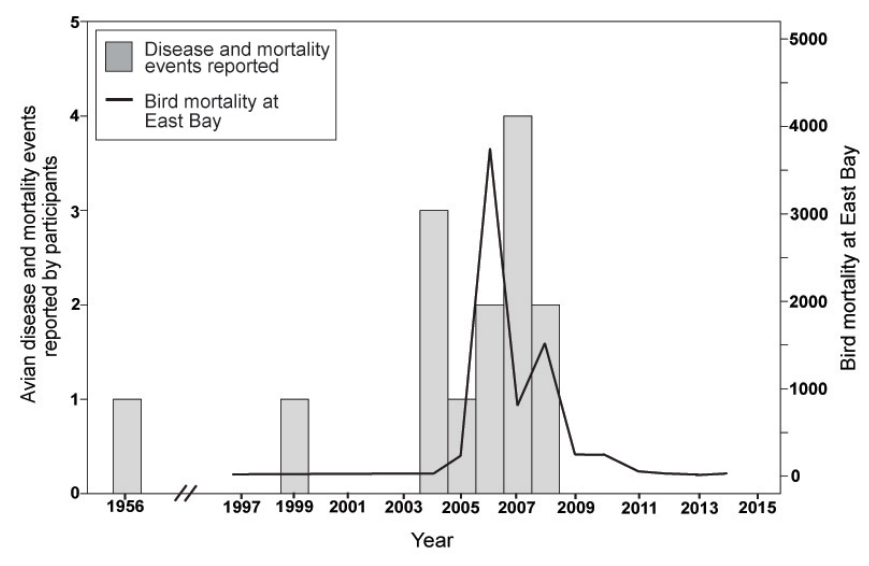

When discussing disease among birds, Inuit participants highlighted three observable indicators of bird sickness, which included both behavioral and physiological indicators (Table 4). In addition, birds described in 36\% (five out of 14) of avian disease or mortality events observed by interviewees presented signs potentially consistent with infection with Pasteurella multocida. Dead birds included eiders, gulls, geese, and murres that were generally unharmed and in good body condition and/or that exuded yellow mucus discharge. Although these symptoms constituted no quantitative confirmation of avian cholera (unless further laboratory analyses were performed), they were nonetheless consistent with scientific understandings of the effects of avian cholera among birds in the wild.

Table 4. Observable indicators of avian disease reported by participants in Kimmirut, Cape Dorset, Coral Harbour, and Igloolik, Nunavut.

\begin{tabular}{ll}
\hline \hline Type of indicator & Description of indicator \\
\hline Behavioral & $\begin{array}{l}\text { Bird laying or floating on its side (unable to hold } \\
\text { head straight) }\end{array}$ \\
& $\begin{array}{l}\text { Bird unable to fly } \\
\text { Physiological }\end{array}$ \\
& $\begin{array}{l}\text { Bird showing yellow mucus around bill or } \\
\text { abdomen }\end{array}$ \\
\hline
\end{tabular}

In addition to providing ecological observations on avian disease and mortality events, some study participants offered explanations and hypotheses as to why they thought the birds they observed were sick or dead. A total of 11 out of 40 interviewees $(28 \%)$ knew about the presence of avian cholera in their region, a phenomenon they had heard about from the radio, the local HTO, or relatives, and three of them stated that some of the sick or dead birds they saw could have been infected by this disease. Two participants from Coral Harbour also explained that the sick or dead birds they observed could have contracted a disease by drinking water from ponds contaminated by bird feces, an observation that is consistent with scientific understanding of avian cholera transmission (Samuel et al. 2007). Last, two residents from each of Kimmirut and Cape Dorset told a similar story (heard from others) about how a lightning strike had caused Common Eider mortality about a century ago.

\section{Observations about Common Eider abundance and distribution}

Respondents were asked about their perceptions about trends and variations in Common Eider abundance and distribution patterns because mass mortality events caused by avian cholera have the potential to change regional eider distribution and population size (Table 1; Descamps et al. 2012, Iverson 2015). Two hunters from Cape Dorset reported an episode of sharp decline in eider numbers during the $1970 \mathrm{~s}$, which they attributed to local overharvesting and excessive egg picking $(2 \mathrm{~B}, 7 \mathrm{~B})$. This was also confirmed by colony surveys (Cooch 1986). Inuit observations in relation to trends in Common Eider abundance over the last 10 years varied greatly from one community to another (Table 3 ). There was no significant consensus within or across the communities of Kimmirut, Cape Dorset, and Igloolik as to whether the Common Eider population in the region had declined, remained stable, or increased over the last decade. By contrast, $70 \%$ of respondents living on Southampton Island (Coral Harbour) had observed a marked increase in the number of Common Eiders nesting in the vicinity of their community.

Finally, 29 respondents $(73 \%)$ reported changes in the geographic distribution of eiders, i.e., mentioned that eiders had moved away from or into a particular area, or were more or less abundant in a particular area. For example, in Coral Harbour, half the interviewees stated that Common Eiders had recently started nesting on Bear Island (Fig. 5) and around a lake close to the community. Although participants discussed a range of factors to explain the changes they noticed in Common Eider abundance and distribution, none of the respondents reported disease as being a factor influencing recent distribution patterns or population trends.

\section{DISCUSSION}

\section{Historical baseline information and population trends}

Testimonies from Inuit participants indicated increasing avian disease and mortality events since 2004 (Fig. 7). Although we acknowledged that the cause of the reported deaths cannot be identified with certainty unless scientific analyses were performed, the timing and nature of Inuit observations we documented were nonetheless coincident with the emergence of avian cholera in the region, which was confirmed through laboratory analyses.

Indeed, respondents did not observe nor report any mass bird mortality event occurring prior to 2004 that could likely be attributed to avian cholera. In fact, two residents from each of Kimmirut and Cape Dorset related a similar story about a Common Eider mass mortality event, which was attributed to a lightning strike on a nesting island about a century ago. Given that avian cholera was first detected in North American wild waterfowl in southern United States in the early 1940s (Gordus 1993, Friend 1999, Friend et al. 2001) and did not exist among wild avifauna in North America prior to that time, it is unlikely that avian cholera could have caused this event. In addition, because outbreaks generally recur episodically among infected 
eider populations (Buttler et al. 2011, Iverson 2015) and that Kimmirut and Cape Dorset residents did not observe any dead birds between the early 1900s and 1999, the four related mass mortality stories did not represent convincing evidence of past avian cholera outbreaks in the South Baffin Island area.

We suspected that the mass mortality event that affected King Eiders in 1956 and that was reported by two participants in Igloolik represented a rare, isolated phenomenon that we found difficult to interpret. In fact, when occurring in the wild in North America, avian cholera outbreaks have been characterized by recurrent, multiyear epidemics, with a large number of colonies affected (CWS 2004, Iverson 2015). Between 1956 and 2009, Igloolik residents travelled regularly to the Calthorpe Islands where families camped and harvested eider eggs during the summer. Throughout that period, no other avian mortality events were reported despite annual visits. These results concur with available scientific knowledge that avian cholera had never been identified in the eastern Canadian Arctic prior to 2004 (Buttler 2009).

We also recognized that most informants were generally unable to distinguish between population changes and variations in eider distribution patterns because of the limited geographical scope of their knowledge. Indeed, most reports of sick or dead birds occurred within a $100 \mathrm{~km}$ radius of the four communities. Nine interviewees pointed out that they "did not know" about eider population trends because they could not distinguish between population changes and variations in eider distribution patterns due to the geographical scope of their knowledge: "I cannot talk about the total quantity of birds. I can only talk about the birds that I saw on the islands. Some people might tell you that there are less eiders now, but this may be because the ducks have moved somewhere else" (10A). Furthermore, of the 21 people who stated that they "did not know" about recent Common Eider population trends, half reported that they could not assess any long-term trend because they observed substantial annual or cyclical variations in eider numbers. One participant stated: "I can't talk about the whole population. Some years there is more. Some years there is less. It changes" (8B). However, respondents generally visited Common Eider colonies at a time of year when eiders were especially vulnerable to avian cholera outbreaks and their observations were effective at detecting unusual events such as avian disease and mortality when it occurred.

\section{Detecting avian disease and mortality events}

Throughout the interview process, many participants were uncomfortable providing detailed quantitative information about the frequency and timing of their visits at specific nesting sites. Despite this, when asked to describe disease and mortality events affecting Common Eiders and other birds, most interviewees could specifically recall the exact year, time of year, and location of such events, and could identify the number of birds and species involved. They also remembered the circumstances of their discovery, whom had accompanied them on their trip, and could describe any visible signs of illness that they had observed among the birds.

Inuit participants who were interviewed were able to provide information on the temporal scope of decades, i.e., over two or three generations, and on the geographical location of avian disease and mortality events within up to $215 \mathrm{~km}$ of their communities. Inuit eider harvesters could recall with confidence their observations of avian disease and mortality events. Indeed, it was Inuit hunters who first encountered and reported dead eiders in the wild that were later confirmed as having died of avian cholera in northeastern Hudson Bay and western Hudson Strait in 2004 (Fig. 1; Iverson 2015). Inuit TEK therefore proved very useful in detecting unusual events among bird populations, and, in this case, drew attention to a wildlife disease outbreak that had previously gone undetected by scientists in the Arctic.

\section{Toward collaborative monitoring}

Collaborative and integrated environmental monitoring involving local Inuit communities and scientific researchers offers several advantages for enhancing our understanding of ecological change in the Arctic (Danielsen et al. 2009, Gofman 2010, Johnson et al. 2015, 2016). In remote northern regions, the high cost of field research and complex logistics pose challenges to scientific data collection (Danielsen et al. 2014). Many individuals in northern communities possess knowledge about the environment they live in (and are a part of), as well as expertise on how to travel in remote locations. Inuit are well positioned to contribute their knowledge and skills in support of collaborative wildlife monitoring initiatives (Ferguson et al. 1998, Krupnik and Jolly 2002, Gilchrist et al. 2005, Gearheard et al. 2011). This case study highlighted some key lessons with regard to the potential contributions (and limitations) of TEK to joint avian disease and wildlife health monitoring, i.e., initiatives including both indigenous or local knowledge and scientific monitoring.

First, in order to better understand the contributions of TEK to collaborative environmental monitoring (such as the monitoring of avian cholera outbreaks among Common Eiders in the Canadian Arctic), the spatial and temporal scales from which TEK and scientific knowledge are derived should be compared. Understanding the geographic and temporal scales at which TEK and scientific observations operate is vital for examining the degree of complementary between TEK and science (Gagnon and Berteaux 2009), as well as for assessing the potential benefits (and limitations) of simultaneously applying these two sources of knowledge to environmental monitoring activities (Gilchrist et al. 2005).

Our case study demonstrated a strong degree of spatial and temporal complementarity between observations of sick or dead birds made by Inuit eider harvesters and those of scientists. Avian cholera outbreaks are often detected by biologists when large aggregations of birds have gathered at stopover sites and breeding colonies (Blanchong et al. 2006). To date, most scientific information on avian cholera among Common Eiders breeding in the Arctic is based on work conducted on a limited number of colonies, and generally on the most populous ones (Buttler 2009, Descamps et al. 2012, Iverson 2015). By contrast, the traditional ecological knowledge presented in this paper was mainly garnered through extensive boat travel by Inuit during their subsistence activities. Study participants mostly observed sick or dead birds floating on the sea or on small nesting islands, rather than as mass mortality events at large nesting colonies. While travelling, Inuit can therefore notice bird disease and mortality events in places not typically monitored by biologists. Although some biologists are able to detect avian cholera at fixed field research sites located in Common Eider nesting colonies (generally of large size), Inuit 
can observe disease and mortality events occurring at sea and along coastlines, which currently go largely undetected by scientists. TEK can also provide information about a larger number of eider nesting colonies (generally of smaller size) that are regularly visited by Inuit as part of egg or down harvesting activities but rarely by scientific researchers. Thus, the spatial data generated through this study (Figs. 3 to 6) can prove helpful to future monitoring of avian disease in the eastern Canadian Arctic by suggesting eider nesting colonies and areas that could be monitored either by Inuit hunters or biologists. Furthermore, Inuit eider harvesters can detect Common Eider disease and mortality events at times that are rarely monitored by biologists. Although the long-term monitoring program initiated at East Bay in 1996 allows biologists to conduct research on Common Eiders throughout the breeding season every year (from June to August), this type of long-term research program is rare in the Canadian Arctic (Gilchrist and Black, unpublished manuscript). Scientific surveys on Common Eiders nesting in the Arctic are most often performed over short periods in the summer months and tend not to be systematically repeated year after year because of their high cost (Iverson 2015). In contrast, Inuit residents make year-round observations of bird species as they carry out livelihood activities on the land and at sea. Inuit harvesters travel specifically to eider colonies for egg and down collection in June and July, a time of year when Common Eiders appear especially vulnerable to avian cholera. In addition, although it was not until the 1970s that substantial scientific baseline data began to be collected on avian species in the Canadian Arctic (Gaston et al. 2012), the testimonies collected as part of this study revealed that Inuit hold historical information transmitted orally over two or three generations on avian disease and mortality events that span about a century.

This study thus offered a second key lesson for collaborative environmental monitoring initiatives involving both scientific researchers and local resource users: although presenting some geographical and temporal limitations that should be acknowledged, TEK can increase the spatio-temporal coverage of monitoring activities (Gagnon and Berteaux 2009). In this case, an examination of the scales from which TEK and scientific knowledge about Common Eiders were derived illustrated that Inuit TEK can increase both the geographic and temporal coverage of avian cholera monitoring in the Canadian Arctic. Results from this study indicated that Inuit TEK can provide observations on avian disease and mortality events over a generally longer and more continuous time series than scientific research typically can, as well as provide information on places, i.e., at sea, along coastlines, and on smaller nesting colonies, that are rarely visited by biologists. However, Inuit TEK about avian disease and mortality also harbored limitations that should be acknowledged. For example, we found that TEK on avian disease and mortality was generated within up to a $215 \mathrm{~km}$ radius of the four surveyed communities, and participants in most cases could not provide detailed quantitative information about the frequency and timing of their visits at specific eider nesting sites. These findings illustrated how combining both Inuit and scientific observations can offer a multiscale approach yielding a better understanding of the spread of avian diseases such as avian cholera.
A third lesson clearly highlighted by our study is that the maintenance of formal or informal communication networks between indigenous or local communities and scientific researchers is crucial for ensuring effective joint environmental monitoring initiatives. Indeed, this work was initially prompted by information exchange between wildlife managers, scientific researchers, and Inuit hunters from Nunavik, who were the first to detect signs of avian cholera outbreaks in the Canadian Arctic in 2004. Over the course of this study, efficient reporting to hunters, HTO members, and local residents by researchers has also fostered the development of mutual trust and respect among project partners and collaborators. Building positive working relationships rooted in good communication is a key element if the goal is to implant long-term monitoring programs in which communities are actively involved in surveillance activities (Gearheard and Shirley 2007, Pearce et al. 2009, Brunet et al. 2014, Danielsen et al. 2014). In addition, because many diseases affecting wildlife (including avian cholera) can only be confirmed through laboratory analyses of infected specimens and their tissues, effective wildlife health monitoring can only occur if adequate communication takes place between resource users, wildlife managers, and scientific researchers (Provencher et al. 2013) in order for tissue samples to be collected from remote locations, transported, and subsequently analyzed in a timely manner.

Last, our experience with this study suggested that, in order for the contribution of TEK (and/or indigenous or local knowledge more generally) to be optimized as part of collaborative environmental monitoring schemes, this source of knowledge should be included in monitoring initiatives in a systematic or regular fashion (Parlee et al. 1998, Krupnik and Jolly 2002). The involvement of local communities in a formalized monitoring of avian disease in the Arctic along with partnership with government agencies, academia, and local organizations could provide relevant information to support local and regional decision-making processes (Danielsen et al. 2009, Johnson et al. 2015). Indeed, local observations and indigenous knowledge have been identified as fundamental practices and corpus of knowledge that should be included in any Arctic observing networks (Gofman 2010, Johnson et al. 2016). To date, community-based monitoring (CBM) initiatives conducted in the Arctic have taken different forms and used different approaches depending on the degree of contribution from both local stakeholders and researchers (Gofman 2010). CBM can be defined as a "process of routinely observing environmental or social phenomena, or both, that is led and undertaken by community members and can involve external collaboration and support of visiting researchers and government agencies" (Johnson et al. 2015). This approach to environmental monitoring has resulted in programs ranging from monitoring carried out only by external researchers with no local involvement, to monitoring entirely undertaken by local communities (Danielsen et al. 2009). Our study reflects a collaborative monitoring scheme with local observations made by Inuit hunters and elders complemented by scientific surveys and TEK documentation done by governmental and academic researchers. Reported observations of avian disease and mortality and concerns expressed in the first place by Inuit hunters to researchers 
suggested a need and interest from local communities to understand the influence of the environmental changes observed on Inuit well-being and tradition (Weatherhead et al. 2010). In addition, Inuit observations of sick or dead birds were part of ongoing livelihood activities such as hunting, egg picking, and down collecting. This integration is fundamental to ensure a successful and sustainable CBM program in which local communities are actively engaged (Mahoney et al. 2009, Danielsen et al. 2014, Johnson et al. 2015).

The surveillance activities described in this study therefore appear well-suited to be further formalized into a community-based monitoring program, especially owing to an already wellestablished communication network ensuring efficient reporting and iterative feedback among community organizations (such as HTOs), researchers, and the Nunavut Wildlife Management Board (NWMB), a territorial comanagement body responsible for the management of wildlife in Nunavut (White 2006, NWMB 2016). Minimally, we recommend that observations of unusual events regarding bird disease and mortality be more systematically reported by local hunters to the NWMB and/or researchers with reinforcement from local HTOs. We believe that extensive surveys such as the one carried out as part of this study could occur regularly, yet not necessarily annually. Indeed, TEK or local knowledge studies should be conducted on a regular basis (or minimally the need for such studies should be regularly reassessed) if local communities are to be meaningfully involved over the long term in the collaborative surveillance of avian disease in the Arctic. Another avenue for formalizing the collaborative monitoring of bird populations in this region would be to have active Inuit hunters document more systematically environmental and harvesting observations related to bird disease and ecology, for example, by using real-time recording tools such as portable, handheld GPS or field computer devices, e.g., the Igliniit project (Gearheard et al. 2011). These local observations could be integrated into existing monitoring programs, such as the NWMB's Community-Based Wildlife Monitoring Network. Since 2012, this monitoring network has compiled wildlife observations and harvesting information recorded by hunters using hand-held computers (NWMB 2017). To date, this initiative has facilitated data sharing among wildlife comanagement partners in support of wildlife management and conservation in Nunavut (NWMB 2017). In order for avian disease surveillance in the Arctic to be successfully formalized, the capacity and interest of local communities to engage in this initiative should also be carefully considered (Johnson et al. 2016). Indeed, regularly reassessing community needs, interests, and capacity is fundamental to create a sense of local ownership in communitybased monitoring (Johnson et al. 2016) and to ensure the longterm success of surveillance programs (Gearheard and Shirley 2007).

Importantly, the wildlife comanagement regime currently in place in Nunavut offers important fora where community members and their representatives can report community concerns and local observations of unusual environmental conditions, such as avian disease and mortality events (White 2006, Gearheard and Shirley 2007, Henri 2012, NWMB 2016). Across the territory, comanagement processes have generated opportunities for various stakeholders to exchange and discuss Inuit and scientific knowledge about the environment (White 2006). However, poor communication among comanagement partners can create misunderstandings and mistrust, and lead to power imbalances (Eddy 2001, Nadasdy 2003, Henri 2012). The success of comanagement in a collaborative environmental monitoring system therefore depends greatly on meaningful, transparent, and inclusive communication practices, which bring together local communities, their representatives, and agencies sitting on comanagement boards (Parlee et al. 1998, Eddy 2001, Berkes et al. 2005, Eamer 2006, Berkes 2009). Wildlife comanagement fora thus offer further opportunities to promote the inclusion of local and indigenous knowledge in the collaborative surveillance of avian disease in the Arctic.

\section{CONCLUSION}

Based on interviews with 40 Inuit participants in four Nunavut communities, we found that Inuit TEK on disease and mortality events of Common Eiders and other bird species provided information on the temporal scope of decades and on a geographical range located within a $215 \mathrm{~km}$ radius of communities. Our findings demonstrated that Inuit TEK was valuable for detecting where disease outbreaks occurred by identifying unusual events, such as bird mortality caused by avian cholera. Although we acknowledged that definitive scientific diagnosis of avian cholera was required by laboratory analyses, this TEK study supported the hypothesis that current and ongoing outbreaks of avian cholera are recent in the eastern Canadian Arctic, having been first detected by Inuit in the mid-2000s. Indeed, the TEK that we gathered suggested that no large-scale avian mortality events likely caused by avian cholera occurred prior to 2004 among Common Eiders and other bird species. That said, we found that there was much individual variation in reports and experience across participants, making it difficult for interviewees to assess whether Common Eider disease and mortality events were related to overall population trends.

Finally, this study illustrated that Inuit eider harvesters detected avian disease and mortality events in places and at times that were rarely monitored by biologists, and thus that their observations can greatly enhance wildlife disease monitoring efforts in the Canadian Arctic on an ongoing basis. At the same time, Inuit TEK collected as part of this work presented some geographical and temporal limitations. Therefore, the strengths but also the limitations of TEK should be acknowledged in order for this important source of knowledge to be meaningfully included and combined with scientific information in joint avian disease and wildlife health monitoring initiatives. The importance of collaboration among resource users, biologists, wildlife disease specialists, and wildlife managers was highlighted by the emergence of avian cholera in the eastern Arctic. Further collaboration among these stakeholders can lead to improved ecological understanding and better information provision on wildlife diseases.

Responses to this article can be read online at: http://www.ecologyandsociety.org/issues/responses. $\mathrm{php} / 9289$ 


\section{Acknowledgments:}

We would like to acknowledge the collaboration of Hunting and Trapping Organizations in Kimmirut, Cape Dorset, Coral Harbour and Igloolik, who gave permission, advice, and support to carry out this work. We are very grateful to all the elders and hunters who shared their knowledge and experience during this project. Many persons provided valuable assistance throughout this study, but special thanks go to Nurluapik Adla, Billy Akpik, Arthur Angootealuk, Louisa Kudluk, Nina Manning Toonoo, John McDonald, Rebecca Mikki, Rhoda Paliak-Angootealuk, Francis Piugattuk, and Pisteolak Pudlat. We would also like to thank Maureen Kay and Amie Black, who arranged the logistics, and Jason Akearok, who helped with the maps. We are grateful to Mark Mallory and five anonymous reviewers for providing insightful comments on earlier versions of this paper. Thank you also to Samuel Iverson for giving permission to use a figure from his doctoral thesis. This study was funded by the Nunavut Wildlife Research Trust, Environment and Climate Change Canada, and the Rhodes Trust. It was conducted under a research license (0103408R-M) from the Nunavut Research Institute.

\section{LITERATURE CITED}

Arctic Climate Impact Assessment (ACIA). 2005. Arctic climate impact assessment. Cambridge University Press, Cambridge, UK.

Arnakak, J. 2000. Commentary: What is Inuit Qaujimajatuqangit? Using Inuit family and kinship relationships to apply Inuit Qaujimajatuqangit. Nunatsiaq News, 25 August.

Berkes, F. 2009. Evolution of co-management: role of knowledge generation, bridging organizations and social learning. Journal of Environmental Management 90(5):1692-1702. https://doi.org/10.1016/ j.jenvman.2008.12.001

Berkes, F. 2012. Sacred ecology: traditional ecological knowledge and resource management. Third edition. Routledge, New York, New York, USA.

Berkes, F., N. Bankes, M. Marschke, D. Armitage, and D. Clark. 2005. Cross-scale institutions and building resilience in the Canadian North. Pages 225-247 in F. Berkes, R. Huebert, H. Fast, M. Manseau, and A. Diduck, editors. Breaking ice: renewable resource and ocean management in the Canadian North. University of Calgary Press, Calgary, Alberta, Canada.

Berkes, F., M. K. Berkes, and H. Fast. 2007. Collaborative integrated management in Canada's North: the role of local and traditional knowledge and community-based monitoring. Coastal Management 35:143-162. http://dx.doi.org/10.1080/089$\underline{20750600970487}$

Berkes, F., and T. Henley. 1997. Usefulness of traditional knowledge: myth or reality? Policy Options 18(3):55-56.

Blanchong, J. A., M. D. Samuel, and G. Mack. 2006. Multispecies patterns of avian cholera mortality in Nebraska's Rainwater Basin. Journal of Wildlife Diseases 42(1):81-91. http:// dx.doi.org/10.7589/0090-3558-42.1.81

Brook, R. M., and S. M. McLachlan. 2005. On using expert-based science to "test" local ecological knowledge. Ecology and Society 10(2):r3. http://dx.doi.org/10.5751/ES-01478-1002r03
Brunet, N. D., G. M. Hickey, and M. M. Humphries. 2014. Understanding community-researcher partnerships in the natural sciences: a case study from the Arctic. Journal of Rural Studies 36:247-261. http://dx.doi.org/10.1016/j.jrurstud.2014.09.001

Buttler, E. I. 2009. Avian cholera among Arctic breeding Common Eiders (Somateria mollissima): temporal dynamics and the role of handling stress in reproduction and survival. Thesis. Carleton University, Ottawa, Ontario, Canada.

Buttler, E. I., H. G. Gilchrist, S. Descamps, M. R. Forbes, and C. Soos. 2011. Handling stress of female Common Eiders during avian cholera outbreaks. Journal of Wildlife Management 75 (2):283-288. http://dx.doi.org/10.1002/jwmg. 38

Canadian Wildlife Service. 2004. Québec management plan for the Common Eider. Special publication of the Joint Working Group on the Management of the Common Eider, Québec. Canadian Wildlife Service, Sainte-Foy, Québec, Canada.

Christensen, T. K. 2008. Factors affecting population size of Baltic Common Eiders (Somateria mollissima). Dissertation. University of Copenhagen, Denmark.

Cooch, F. G. 1986. The numbers of nesting northern eiders on the West Foxe Islands, NWT. Pages 114-118 in A. Reed, editor. Eider ducks in Canada. Canadian Wildlife Service, Ottawa, Ontario, Canada.

Danielsen, F., N. D. Burgess, A. Balmford, P. F. Donald, M. Funder, J. P. G. Jones, P. Alviola, D. O. Balete, T. Blomley, J. Brashares, et al. 2009. Local participation in natural resource monitoring: a characterization of approaches. Conservation Biology 23(1):31-42. http://dx.doi.org/10.1111/j.1523-1739.2008.01063. $\underline{\mathrm{x}}$

Danielsen, F., E. Topp-Jørgensen, N. Levermann, P. Løvstrøm, M. Schiøtz, M. Enghoff, and P. Jakobsen. 2014. Counting what counts: using local knowledge to improve Arctic resource management. Polar Geography 37(1):69-91. http://dx.doi. org/10.1080/1088937X.2014.890960

Descamps, S., H. G. Gilchrist, J. Bêty, E. I. Buttler, and M. R. Forbes. 2009. Costs of reproduction in a long-lived bird: large clutch size is associated with low survival in the presence of a highly virulent disease. Biology Letters 5:278-281. http://dx.doi. org/10.1098/rsbl.2008.0704

Descamps, S., S. Jenouvrier, H. G. Gilchrist, and M. R. Forbes. 2012. Avian cholera, a threat to the viability of an Arctic seabird colony? PLoS ONE 7(2):e29659. http://dx.doi.org/10.1371/ journal.pone.0029659

Duerden, F., and R. G. Kuhn. 1998. Scale, context, and application of traditional knowledge of the Canadian North. Polar Record 34(188):31-38. http://dx.doi.org/10.1017/ S0032247400014959

Eamer, J. 2006. Keep it simple and be relevant: The first ten years of the Arctic Borderlands Ecological Knowledge Co-op. Pages 185-206 in W. V. Reid, F. Berkes, T. Wilbanks, and D. Capistrano, editors. Bridging scales and knowledge systems. Millennium Ecosystem Assessment and Island Press, Washington, D.C., USA. 
Eddy, S. 2001. Tuktoyaktuk and Aklavik Tariuq (Ocean) community-based monitoring program. Fisheries and Oceans Canada Report, Aklavik, Northwest Territories, Canada.

Ferguson, M. A. D., and F. Messier. 1997. Collection and analysis of traditional ecological knowledge about a population of Arctic tundra caribou. Arctic 50(1):17-28. http://dx.doi.org/10.14430/ $\underline{\operatorname{arctic} 1087}$

Ferguson, M. A. D., R. G. Williamson, and F. Messier. 1998. Inuit knowledge of long-term changes in a population of Arctic tundra caribou. Arctic 51(3):201-219. http://dx.doi.org/10.14430/ arctic1062

Friend, M. 1999. Avian cholera. Pages 75-92 in M. Friend and J. C. Franson, editors. Field manual of wildlife diseases: general field procedures and disease of birds. Biological Resources Division, Information and Technology Report 1999-2001. U.S. Geological Survey, Reston, Virginia, USA.

Friend, M. 2006. Disease emergence and resurgence: the wildlifehuman connection. U.S. Geological Survey Circular 1285.

Friend, M., R. G. McClean, and F. J. Dein. 2001. Disease emergence in birds: challenges for the twenty-first century. Auk 118:290-303. http://dx.doi.org/10.1642/0004-8038(2001)118[0290: DEIBCF]2.0.CO;2

Gagnon, C. A., and D. Berteaux. 2009. Integrating traditional ecological knowledge and ecological science: a question of scale. Ecology and Society 14(2):19. http://dx.doi.org/10.5751/ ES-02923-140219

Gaston, A. J., M. L. Mallory, and H. G. Gilchrist. 2012. Populations and trends of Canadian Arctic seabirds. Polar Biology 35:1221-1232. http://dx.doi.org/10.1007/s00300-012-1168-5

Gearheard, S., C. Aporta, G. Aipellee, and K. O'Keefe. 2011. The Igliniit project: Inuit hunters document life on the trail to map and monitor Arctic change. Canadian Geographer 55(1):42-55. http://dx.doi.org/10.1111/j.1541-0064.2010.00344.x

Gearheard, S., and J. Shirley. 2007. Challenges in communityresearch relationships: learning from natural science in Nunavut. Arctic 60(1):62-74. http://dx.doi.org/10.14430/arctic266

Gilchrist, H. G., M. L. Mallory, and F. Merkel. 2005. Can local ecological knowledge contribute to wildlife management? Case studies of migratory birds. Ecology and Society 10(1):20. http:// dx.doi.org/10.5751/ES-01275-100120

Gilliland, S. G., H. G. Gilchrist, R. F. Rockwell, G. J. Robertson, J.-P. L. Savard, F. Merkel, and A. Mosbech. 2009. Evaluating the sustainability of harvest among Northern Common Eiders Somateria Mollissima in Greenland and Canada. Wildlife Biology 15(1):24-36. http://dx.doi.org/10.2981/07-005

Gofman, V.2010. Community-basedmonitoring handbook: lessons from the Arctic. CAFF CBMP Report No.21, CAFF International Secretariat, Akureyri, Iceland.

Gordus, A. G. 1993. Notes on the first known avian cholera epizootic in wildfowl in North America. Journal of Wildlife Diseases 29:367. http://dx.doi.org/10.7589/0090-3558-29.2.367

Goudie, R. I., G. J. Robertson, and A. Reed. 2000. Common Eider (Somateria mollissima). In P. G. Rodewald, editor. The birds of
North America. Cornell Lab of Ornithology, Ithaca, New York, USA. http://dx.doi.org/10.2173/bna.546

Government of Canada. 2016. Census Profile, 2016 Census. Statistics Canada, Ottawa, Ontario, Canada. [online] URL: http://www12.statcan.gc.ca/census-recensement/2016/dp-pd/prof/ index.cfm? Lang $=\mathrm{E}$

Harms, N. J. 2012. Exploring health and disease in Northern Common Eiders in the Canadian Arctic. Arctic 65(4):495-499. http://dx.doi.org/10.14430/arctic4255

Henri, D. 2012. Managing nature, producing cultures: Inuit participation, science and policy in wildlife governance in the Nunavut Territory, Canada. Dissertation. University of Oxford, UK.

Henri, D. 2007. The integration of Inuit traditional ecological knowledge and western science in wildlife management in Nunavut, Canada: the case of avian cholera outbreaks among Common Eider ducks in the west Hudson Strait and north Hudson Bay area. Thesis, University of Oxford, UK.

Henri, D., H. G. Gilchrist, and E. Peacock. 2010. Understanding and managing wildlife in Hudson Bay under a changing climate: some recent contributions from Inuit and Cree ecological knowledge. Pages 267-289 in S. H. Ferguson, L. L. Loseto, and M. L. Mallory, editors. A little less Arctic: top predators in the world's largest northern inland sea, Hudson Bay. Springer, Dordrecht, The Netherlands. http://dx.doi.org/10.1007/978-90-481-9121-5 13

Houde, N. 2007. The six faces of traditional ecological knowledge: challenges and opportunities for Canadian co-management arrangements. Ecology and Society 12(2):34. http://dx.doi. org/10.5751/ES-02270-120234

Huntington, H. P. 1998. Observations on the utility of the semidirective interview for documenting traditional ecological knowledge. Arctic 51:237-242. http://dx.doi.org/10.14430/ $\underline{\operatorname{arctic} 1065}$

Iverson, S. L. 2015. Quantifying the demographic and population impact of avian cholera on Northern Common Eiders in the face of ancillary threats and changing environmental circumstances. Dissertation. Carleton University, Ottawa, Ontario, Canada.

Johnson, M. 1992. Research on traditional environmental knowledge: its development and its role. Pages 3-22 in M. Johnson, editor. Lore: capturing traditional environmental knowledge. Dene Cultural Institute and the International Development Research Centre, Hay River, Northwest Territories, Canada.

Johnson, N., L. Alessa, C. Behe, F. Danielsen, S. Gearheard, V. Gofman-Wallingford, A. Kliskey, E. M. Krümmel, A. Lynch, T. Mustonen, P. Pulsifer, and M. Svoboda. 2015. The contributions of community-based monitoring and traditional knowledge to Arctic observing networks: reflections on the state of the field. Arctic 68(5):1-13. http://dx.doi.org/10.14430/arctic4447

Johnson, N., C. Behe, F. Danielsen, E. M. Krümmel, S. Nickels, and P. L. Pulsifer. 2016. Community-based monitoring and indigenous knowledge in a changing arctic: a review for the Sustaining Arctic Observing Networks. Final report to Sustaining Arctic Observing Networks. Inuit Circumpolar Council, Ottawa, Ontario, Canada. 
Kitchin, R., and N. Tate. 2000. Conducting research in human geography: theory, methodology and practice. Pearson Education, Harlow, UK.

Krupnik, I., and D. Jolly, editors. 2002. The Earth is faster now: indigenous observations of Arctic environmental change. ARCUS, Fairbanks, Alaska, USA.

Legagneux, P., L. L. Berzins, M. Forbes, N. J. Harms, H. L. Hennin, S. Bougeon, H. G. Gilchrist, J. Bêty, C. Soos, O. P. Love, J. T. Foster, S. Descamps, and G. Burness. 2014. No selection on immunological markers in response to a highly virulent pathogen in an Arctic breeding bird. Evolutionary Applications 7:765-773. http://dx.doi.org/10.1111/eva.12180

Lévesque, F. 2014. Revisting Inuit Qaujimajatuqangit: Inuit knowledge, culture, language, and values in Nunavut institutions since 1999. Études/Inuit/Studies 38(1-2):115-136.

Mahoney, A., S. Gearheard, T. Oshima, and T. Qillaq. 2009. Sea ice thickness measurements from a community-based observing network. Bulletin of the American Meteorological Society 90 (3):370-377. http://dx.doi.org/10.1175/2008BAMS2696.1

Mailhot, J. 1993. Traditional ecological knowledge. The diversity of knowledge systems and their study. Great Whale Public Review Support Office, Montréal, Québec, Canada.

Mallory, M. L., A. J. Fontaine, J. A. Akearok, and V. H. Johnston. 2006. Synergy of local ecological knowledge, community involvement and scientific study to develop marine wildlife areas in eastern Arctic Canada. Polar Record 42(3):205-216. http://dx. doi.org/10.1017/S0032247406005481

Mallory, M. L., H. G. Gilchrist, A. J. Fontaine, and J. A. Akearok. 2003. Local ecological knowledge of Ivory Gull declines in Arctic Canada. Arctic 56(3):293-298. http://dx.doi.org/10.14430/ $\underline{\operatorname{arctic} 625}$

Mauro, F., and P. D. Hardison. 2000. Traditional knowledge of indigenous and local communities: international debate and policy initiatives. Ecological Applications 10(5):1263-1269. http:// dx.doi.org/10.1890/1051-0761(2000)010[1263:TKOIAL]2.0.CO;2

Mosbech, A., G. Gilchrist, F. Merkel, C. Sonne, A. Flagstad, and H. Nyegaard. 2006. Year-round movements of Northern Common Eiders Somateria mollissima borealis breeding in Arctic Canada and West Greenland followed by satellite telemetry. Ardea 94(3):651-665.

Nadasdy, P. 2003. Reevaluating the co-management success story. Arctic 56:367-380. http://dx.doi.org/10.14430/arctic634

Nakashima, D. J. 1991. The ecological knowledge of Belcher Island Inuit. Dissertation. McGill University, Montréal, Québec, Canada.

Nunavut Wildlife Management Board (NWMB). 2004. Nunavut wildlife harvest study. Nunavut Wildlife Management Board, Iqaluit, Nunavut, Canada.

Nunavut Wildlife Management Board (NWMB). 2016. 2014-2015 Annual report. Nunavut Wildlife Management Board, Iqaluit, Nunavut, Canada. [online] URL: http://www.nwmb.com/ en/publications/annual-reports/5770-2014-2015-annual-report-inukinn-eng
Nunavut Wildlife Management Board (NWMB). 2017. 2015 Report to Public on CBMN first three years. Nunavut Wildlife Management Board, Iqaluit, Nunavut, Canada. [online] URL: https://www.nwmb.com/inu/cbmn/reports

Parlee, B., and Lutsel K'E Dene First Nation. 1998. A guide to community-based monitoring for northern communities. Northern Mineral Program Working Paper No. 5. Canadian Arctic Resources Committee, Ottawa, Ontario, Canada.

Pearce, T .D., J. D. Ford, G. J. Laidler, B. Smit, F. Duerden, M. Allarut, M. Andrachuk, S. Baryluk, A. Dialla, P. Elee, A. Goose, T. Ikummaq, E. Joamie, F. Kataoyak, E. Loring, S. Meakin, S. Nickels, K. Shappa, J. Shirley, J. Wandel. 2009. Community collaboration and climate change research in the Canadian Arctic. Polar Research 28(1):10-27. http://dx.doi.org/10.1111/

j.1751-8369.2008.00094.X

Pierotti, R., and D. Wildcat. 2000. Traditional ecological knowledge: the third alternative. Ecological Applications 10 (5):1333-1340. http://dx.doi.org/10.1890/1051-0761(2000)010[1333: TEKTTA]2.0.CO;2

Provencher, J. F., M. McEwan, M. L. Mallory, B. M. Braune, J. Carpenter, N. J. Harms, G. Savard, and H. G. Gilchrist. 2013. How wildlife research can be used to promote wider community participation in the North. Arctic 66(2):237-243. http://dx.doi. org/10.14430/arctic4302

Reed, A. 1986. Eiderdown harvesting and other uses of common eiders in spring and summer. Eider ducks in Canada. Canadian Wildlife Service Report Series 138-146.

Riedlinger, D., and F. Berkes. 2001. Contributions of traditional knowledge to understanding climate change in the Canadian Arctic. Polar Record 37(203):315-328. http://dx.doi.org/10.1017/ $\underline{\mathrm{S} 0032247400017058}$

Robertson, G. J., and H. G. Gilchrist. 1998. Evidence of population declines among Common Eiders breeding in the Belcher Islands, Northwest Territories. Arctic 51(4):378-385. http://dx.doi.org/10.14430/arctic1081

Rubin, H. J., and I. S. Rubin. 2005. Qualitative interviewing: the art of hearing data. Sage, London, UK. http://dx.doi. org/10.4135/9781452226651

Samuel, M. D., R. G. Botzler, and G. Wobeser. 2007. Avian cholera. Pages 239-269 in N. J. Thomas, D. B. Hunter, and C. T. Atkinson, editors. Infectious diseases of wild birds. Blackwell, Ames, Iowa, USA. http://dx.doi.org/10.1002/9780470344668. $\underline{\operatorname{ch} 12}$

Samuel, M. D., D. J. Shadduck, D. R. Goldberg, and W. P. Johnson. 2005. Avian cholera in waterfowl: the role of Lesser Snow and Ross's Geese as disease carriers in the Playa Lakes Region. Journal of Wildlife Disease 41:48-57. http://dx.doi. org/10.7589/0090-3558-41.1.48

Savard, J.-P. L., L. Lesage, S. G. Gilliland, H. G. Gilchrist, and J.-F. Giroux. 2011. Molting, staging, and wintering locations of Common Eiders breeding in the Gyrfalcon Archipelago, Ungava Bay. Arctic 64(2):197-206. http://dx.doi.org/10.14430/arctic4099

Usher, P. J. 2000. Traditional ecological knowledge in environmental assessment and management. Arctic 53 (2):183-193. http://dx.doi.org/10.14430/arctic849 
Wenzel, G. W. 2004. From TEK to IQ: Inuit Qaujimajatuqangit and Inuit cultural ecology. Arctic Anthropology 41(2):238-250. http://dx.doi.org/10.1353/arc.2011.0067

Weatherhead, E., S. Gearheard, and R. G. Barry. 2010. Changes in weather persistence: insight from Inuit knowledge. Global Environmental Change 20(3):523-528. http://dx.doi.org/10.1016/ j.gloenvcha.2010.02.002

White, G. 2006. Cultures in collision: traditional knowledge and Euro-Canadian governance processes in northern land-claim boards. Arctic 59(4):401-414. http://dx.doi.org/10.14430/arctic289

Whytes, K. P. 2013. On the role of traditional ecological knowledge as a collaborative concept: a philosophical study. Ecological Processes 2(7):1-12. http://dx.doi.org/10.1186/2192-1709-2-7 